\title{
Afro-pessimism and globalization: the stakes of symbolic death of Africa, https://dx.doi.org/10.4314/rj.v2i2.2A
}

Dr. Aimable Mugarura Gahutu

School of Languages, CASS, University of Rwanda

\begin{abstract}
This research strives to present the complexity of the Afro-pessimist concept, the conditions which made it possible and the way it is expressed on a daily basis. Straightaway, we need to precise that Afro-pessimism has a long pre-history. It is to be placed in the continuity of negative discourses towards Africa and Africans, the very discourses that conferred legitimacy to slavery and colonization. Yet, Afro-pessimism is a new and trend-related discourse arising after the collapse of the Berlin Wall. So, as a matter of fact, it is a discourse of/on ruin and collapse: the whole set of values preceding the collapse of the wall collapsed with the wall to make room for a new order. Thus, Africa is fated to imminent collapse since the new order, globalization, has nothing to sacrifice to the strategic stakes which were so profitable to the continent. The Cold War is just a bad memory now. The stakes of the new discourse are therefore clear: assistance to development has become an obsolete notion which is synonymous with squandering capital. Henceforth, Africa must take the pace of world economy and contribute to production according to the new standards of globalized capital: local governments and firms must renounce their capital in favor of multinational companies. Globalization means symbolic death for Africa. It is total destruction since not a single sector will be spared, even the culture and environment are hurt.
\end{abstract}

Key words: Afro-pessimism, globalization, social discourse, otherness.

\section{Introduction}

The turn of the $20^{\text {th }}$ century is characterized by a tangible global discontent: all-out violence, internal and international political crises, zero-tolerance attitudes which aggravate all kinds of extremisms, unemployment and the ever-growing gap between the rich and the poor; the list is far from being exhausted. The authors of this paper interpret 
this state of affairs as the result of a crisis in thinking, as lack of positive values on the part the elites. Values are totally devoted to globalization.

Africa cannot escape this pervading pessimism, but it is through a particular discourse that Africa is talked about. Already over the past ten years, the image of Africa which has been fostered by the Western world is hopeless, to say the least. The widespread idea with the historians, the economists and the political analysts at the end of the $20^{\text {th }}$ century is that the black continent is going through the darkest period of its history as a result of the multifaceted failure undermining it. And as that was not bad enough for its misfortune, Africa can no longer rely on the great powers' assistance to get out of it. They are not interested in Africa at all since its strategic importance was linked to the context of the Cold War which is obsolete now.

From the media to international meetings through cultural and artistic expression, this pessimism is well thought of. From the moment continent was looked at through pessimistic lenses, its positive realities are overlooked in favor of the agonizing image of Africa. Hunger, disease, poverty, debt, civil war, corruption, and bad governance are all the continent's typical features which compete for headlines in the press and television programs. And, unfortunately, it is this long list of the evils of Africa which reinforces and gives legitimacy to "Afro-pessimism", an opinion that proclaims loudly, "noir c'est noir, il n' y a pas d'espoir" [black is black, it is hopeless] - to use the wording of a French rocker. ${ }^{1}$

However, Afro-pessimism remains a controversial concept, depending on the side where you are. Though many Western researchers generally agree on the concept of Afropessimism, some African university analysts blame it for its biased vision of the continent's reality. Catherine Coquery-Vidrovitch summed up the debate dividing both geopolitical entities over the concept as follows:

\footnotetext{
${ }^{1}$ These are the words of Johnny Halliday which caused his being expulsed from Kinshasa, the Capital-City of the Democratic Republic of the Congo, where he was to stage a concert.
} 
We must $[\ldots]$ be careful with the difference in meaning the word [Afro-pessimism] involves when used in the Western world and in Africa. In France, [...] it is a question of political idea. In Africa, the word corresponds more to some reality, one about the grimness of daily life and the difficulty to make out the way to the remedy, in the short term of course, but also in a concerted manner. [...] Afropessimism as seen by Europe is then only a point of view. But what is fearsome is that it is a matter of an explicit political will, or better, unconscious (especially with leftist intellectuals); one which would keep Africa dependent, or at least, would continue to consider Africa as inferior.

In light of this precision, the concept is a subjective creation, an opinion which, from the viewpoint of concrete observation, all the same involves a political intention thinly disguised. Indeed, we know since Austin that "dire c'est faire" [speech is action].

To go upstream the genealogy of Afro-pessimism, still with Coquery-Vidrovitch, the term was born within the circle of Jimmy Carter, former president of the United States and its emergence coincided with the period when Berlin Wall collapsed. With a broad coverage in the media, first by the New York Herald, then by the French press, respectively le Figaro, le Point, l'Express, le Nouvel Observateur and l'Evénement du Jeudi, Afro-pessimist discourse prevailed and announced the establishment of a geopolitical new deal for Africa. Actually, "the media explained to us that not only had Africa fallen the lowest possible, but worse, would never be able to recover, that we were sighting the agony of a continent somehow ready to be deleted from the international geopolitical map." (1). It is to this semantic and strategic complexity in the Western meaning of the term that henceforth, refers the use of the term "Afro-pessimism."

Another complexity concealed by this concept lies in the political circle that originated it: Jimmy Carter's administration. Paradoxically, the same political figure created a humanitarian, political and scientific Foundation dedicated to Africa. Why should Africa then mistrust Carter whose pessimistic acknowledgement about Africa seems to be well meaning? The reason is that one discourse may conceal another. Kerbrat-Orecchioni 
rightly noted in L'Implicite (1989) that not everybody talks in a straight way. Otherwise, communication would be easier.

Besides, in addition to its overtly disparaging content, the construction of the concept draws attention on itself: "Afro-pessimism" is a compound neologism. And where word formation is concerned, Roland Barthes created one himself and called it portmanteau word. It is a lexical unit stemming from a play on words consisting in forming a new word through the association of certain syllables borrowed from several words in order to produce a shock effect. Playing on words or playing with words is the first characteristic of political discourse, especially when this discourse turns itself into propaganda. There are many examples of this: "voyou-cratie" [government by rascals] ${ }^{2}$, "socio-fascist", etc. Therefore, from the very beginning, "Afro-pessimism" seems to be fated to a big political and ideological fortune. Very efficient as it is, it cumulates the functions of acknowledgement, action plan, and pragmatic standards according to the point of view one adopts. The latter function is particularly interesting in that while creating legitimacy on the one hand, and discrimination on the other hand, Afro-pessimism somehow brings together the dominant group(s) who must harmonize speech with action. Marc Angenot makes the precision that "legitimate discourses function less to controlling the dominated [...] than to rallying, motivating and keeping busy the minds of the dominant who must be convinced in order to believe." (1989: 27).

In this context of global depression, the exasperation expressed by the Western world in the evocation of Africa would in the end come to its own projection onto an outlet otherness or scapegoat, a simple microcosm in line with world macrocosm. Global pessimism then functions as backcloth to a specific pessimism, Afro-pessimism. In these conditions, we need take the evils of Africa relatively. Because this continent is not the only one to be sick since the sunset vision of the world is henceforward is a contemporary atmosphere.

\footnotetext{
2 « voyou-cratie » is a compound neologism from « voyou »[rascal] and "cratie" [government or leadership] which is impossible to translate in English in this compact form. Paraphrased "voyou-cratie" means "government by rascals".
} 
It would be also interesting to check to which extent the denomination "Africa" corresponds in Western discourse to a reality which is often mythic, with constantly fluctuating outlines. Rather than an objective and stable geographical referent, Africa is subjectivised in common discourse, as a wild and anarchical space. For example, it is common to hear a radio commentator get annoyed and say: "it's as if we were in Africa!" when faced with damages in a Western city following a demonstration against globalization or an important power outage. Africa would be, in a case like this one, negative otherness. In other words, everything the West is not ready to assume.

\section{Notional tools and methodological approach}

The study of postulates made against Africa and Africans by more or less well organized collective entities naturally fits in with the field of "social discourse" in the wider sense which Marc Angenot acknowledges in this notion: "generic systems, topical catalogues, laws on the order of succession of utterances which, in a given society, organize the expressible - the narratable and the nodable - and ensure the division of discourse work." (1989, 13). Afro-pessimistic statements contained in various texts are regulated by a rhetoric, by some efficient principle which, to be properly delineated, require the use of the discourse analysis model elaborated by Marc Angenot. The study of Afro-pessimist discursive practices will use the same process as socialist propaganda (1889-1914). ${ }^{3}$ Despite the obvious sociolectal specificity (Afro-pessimism rather belongs to the paradigm of "capitalistic" propaganda") which we acknowledge in each of these topical fields, it is imperative to note that their discursive strategy is essentially parallel. Actually, they are all the same strategic processes to rouse the passions of the same and subdue the passions of the Other: doxological orchestration, legitimization, persuasion, memorization and mobilization. From this viewpoint, it is advised and legitimate to use the methodological tools proposed by Angenot, essentially where the rhetoric of argumentation is concerned.

\footnotetext{
${ }^{3}$ Marc Angenot, La propaganda socialiste. Six essays d'analyse du discourse. Analysis no 1 studying the functions and the pragmatics of propaganda is particularly interesting for us.
} 
Afro-pessimism is henceforward perceived as the "Grand Narrative" regulating the North/South relationships and outshining any discursive competition during this $20^{\text {th }}$ century transition. The achievement of its hegemonic function is far from being random. It is the result of a series of tactical mechanisms which conquer all the instances of discourse, from the lexicon to pragmatics, through the rhetorical aspect.

On the basis of various texts on Africa (end of $20^{\text {th }}$ and beginning of $21^{\text {st }}$ centuries), it is a question of identifying, in the first place, utterances that were semantically equivalent with overt or latent Afro-pessimism; then, these utterances will be studied both qualitatively ( denotations and connotations) and quantitatively (regularity, frequency); and afterwards, discourse analysis will attempt to formulate the rules that define the rhetorical tendencies of the discourse on Africa and to ensure its efficiency. But already, we are formulating the hypothesis that Afro-pessimist discourse of the $20^{\text {th }}$ century transition fits in the register of "disruption", "rift" and "gap" according to the "archeology of knowledge" studied by Michel Foucault. On the other hand, Afropessimist discourse borrows from the Roman model the notion of "barbarian", thus appealing to the theory of otherness.

\section{From the collapse of the Berlin Wall to the new world order}

Of all events, the collapse of the Berlin Wall irreversibly changed the course of history. The event was a deep chronological rift that is a necessary reference for historians. These rightly acknowledge the historical importance of this event in the usual formula "Nothing will look like previously" after this date.

The collapse of the wall indeed marked the end of a world balance of many centuries and so disrupted order and continuity. Even more, it confused the historians used to the conception of history as a linear succession of events in terms of cause-and-effect. In fact, though it is undeniable that on the one hand the reality of the wall collapse owes much to the successive socio-historical facts that prepared November 9, 1989 and, on the other hand, certainly involves an impact for anything coming after 1989 in conformity with the traditional perspective abiding by the biological model of evolution, it is nonetheless true 
that concerning the collapse of the wall, it is better to talk of "disruption", "rift" and "gap" (Foucault, Archéologie, 221)) in the course of history. In this capacity, it would be better for this symbolic moment if it was considered through the archeological sign as a historical irregularity.

Michel Foucault critical remarks on traditional history which has an attachment for "continuity" find their full meaning with the collapse of this monument. For the philosopher, in its classic practice, history, much concerned with "regularity" and "continuity", is inclined to deny their due importance to events that disrupt tradition, since they are blurred or twisted by the course of History:

For history in its classic form, discontinuity was both the given and the unthinkable: that which occurred under the form of disparate events - decisions, accidents, initiatives, discoveries; and that which should be, through analysis contorted, reduced, and subdued, for the continuity of events to prevail. Discontinuity was the blemish of time dissipation which it was the duty of the historians to delete from history. It has now become one of the fundamental elements of historical analysis (1969: 16).

Considered under this synchronic approach, the collapse of the wall eludes the monotonous and regular linearity of events and really makes history since it is viewed in itself as the "limit of a process, the point where a curve bends, the inversion of a regulating movement, the bounds of an oscillation, the threshold of a working system, and the break-down of a circular causality" (17)

This choice in favor of archeology at the expense of the history of ideas has an advantageous methodological effect for this study. Giving greater importance to synchrony rather than follow the linearity of events and actions which insidiously undermined the wall over the years, the debate from that moment was over the unique fundamental issue for us, that is, the presence and the absence of the "wall" and the resulting consequences. 
We do agree that absence is often more interesting or even more important than presence. This is invaluable concerning the Berlin Wall whose collapse affected the remotest points in the world. Paradoxically, the new order which this event imposed affects more the peripheries when the epicenter of the wave shock, far from being disturbed, wins all the way, especially economically. The Third-World is obviously be penalized most by triumphant capitalism which succeeds to the previous order.

Men, women and children in peripheral countries are actually double victims. Due to the devastations sustained in the past, due to unequal development between their societies and the societies of former colonial countries of the Northern hemisphere, they are now at the time of globalization, of the unique economic and thought model - unable to resist the new attacks from transcontinental capital. [...] In short, globalization hits hard a social group which was already seriously weakened and deprived of its immune resistance forces. (Ziegler, Les Nouveaux Maitres, 31). Obviously, it is also at the expense of Western social strata in the lower classes since it is the very nature of capitalism, or at least its code of ethics, not to make the protection of the working mass a priority concern. There is a good reason to this: pressure on the employers which in the past was secured by the leftist vote is not as strong now since the collapse of communism in the Soviet Union.

Concerning Africa specifically, after the generous support benefits from the Soviet Bloc in its liberation struggle against colonization, the collapse of the Berlin Wall and the implosion of USSR were due to entail more serious consequences on it. Africa was deprived, or about to be deprived of assistance to development and of cooperation which had been dependent on the competition among superpowers that used to share the continent during the Cold War era. It is during this economic climate that rose discourses which keep rehearsing the death of the continent. In this capacity, Afro-pessimism is a direct consequence of the collapse of the war which entailed the end of interest in Africa. 


\section{Death of the Other as essence of globalization}

Being the end of an era, a new geopolitical deal on world level, an epistemological threshold, the collapse of the wall is the disruption which allows the passage without any transition from the cold war to globalization, from the bipolar system to a one-pole system, from the status of superpower (The United States of America and USSR) to the status of hyperpower. The empire, after the fashion of Ancient Rome, had just been born. The analogy between the American empire and Rome is of high interest - with the reserve that historical comparisons often lead to errors as there are never two identically similar situations - in that it allows us to make a first order acknowledgement: every empire needs an enemy to exist. The same way Rome became an empire after defeating Carthage, the American empire was born when the threat of USSR for the United States definitely stopped to exist in 1991, another turning-point date. Rome always defined itself on the backcloth of something else; it is a city which first of all fought her neighbors and afterwards sought her enemies farther and farther. When the people of Carthage was defeated, an "obsessional search" for an enemy followed, to use the words of Jean Christophe Rufin in L'Empire et les nouveaux barbares. After the real and known enemy, Carthage, the nature of the enemy was more diffuse: anything that was not Rome, that is, the Barbarians. On the one hand, Rome was the incarnation of civilization; on the other hand, there was the whole set of small savage peoples by the borders of the empire.

The same thing is quite observable in the present context of the reign of the American empire. The former USSR not being a threat any more, the enemy of the United States has become as blurred and shifting as he was everywhere and nowhere. The enemy is henceforward everything that is otherness, even when it is not an immediate threat like the destitute and the rejected in general. Nobody eludes the Empire's paranoiac susceptibilities while economic surveillance and enslavement is the most efficient way to wage this preventive and permanent war. Then, it becomes clear that beyond the religious stakes which are often evoked as a bone of contention between the West in general and its new enemy, the new motivation is rather economic and this conflict may come down to the opposition between the rich and the poor, and to the unequal distribution of wealth. 
The enemy is for the Empire a necessary and useful evil as it was proved that the economies are drawn by military expenses. Paradoxical though it may be, when there is no looming war, the economies stagnate; which is ultimate evidence that the sinews of war and war itself are closely interdependent. For example, with the fall of the Berlin Wall, the big capitalistic financial circles could make a choice between peace and war to organize the new world society. As Ziegler reported, rather than trusting the multinational organizations like the UN which guarantee collective security, they chose the option of war, banking on "the striking power of the American superpower. Instead of international conflict resolution among nations, they chose the diktat of the American empire $[\ldots]$, the violence of the strong." (42) It is in this way that the military power built in the context of the Cold War is used now to "implement and protect the order of globalized financial capital. This colossal imperialistic machinery is developing in a quasi- autonomous way. [...] Inherited from the Cold War and revitalized, it adds its own violence to the violence of capital.”(43)

To come back to the parallelism with the Roman Empire, the American Empire is positioned on an infinitely more subtle and more sophisticated ground, one of the war of capitals. At this level, the nuance to use carefully between the policies of the respective empires is as follows. While the Roman Empire is entirely based on land conquest ("empire policy"), the United States to a large extent practices a policy of ascendancy corresponding to an invisible presence, under the anonymity of capital. Of course, we must recognize on the one hand that the Roman conquests being not only motivated by the simple pleasure to subjugate the Barbarians; greed for wealth is not a modern invention. On the other hand, the United States has some military presence in the four corners of the world. However, we need to precise that the economic war machinery of the American empire has no possible comparison with the military arsenal which, besides, is subordinated to it:

The military presence formerly built to face the Soviet Union is now used to implement and to protect the order of globalized capital. This colossal imperialistic machinery is developing in a quasi-autonomous way. It has its own laws, its 
specific dynamics. Inherited from the Cold War and revitalized, it adds its own violence to the violence of capital (Ziegler 43).

The war of capitals, if far more fearsome, subjugates States and governments with no bloodshed. Even more, it usurps the world by globalizing the economies, by privatizing world resources. It is in this sense that we need to understand the policy of ascendancy of the United States, unscrupulous and undivided ascendancy over the working of the international system; ascendancy which, symbolically, means death of the Other.

\section{Conclusion}

Afro-pessimism is a meta-critical concept compounding all the discourses which enumerate the evils of the continent which they claim to have no remedy. The object of this paper was the study of Afro-pessimism, the context which allowed the emergence of the concept, the conditions which made it possible and its coincidence with globalization. Our project was to organize its disparate controversial arguments found in various texts into a coherent discursive system. We were able to show that this discourse marks a new relationship between Africa and the West: the discourse of assistance to development of the eighties was replaced by the discourse of globalization. This is what turns Afropessimism into a very important epistemological landmark.

By studying the background of the concept, we have identified its coincidence with the collapse of the Berlin Wall and globalization. This way, we verified the hypothesis that Afro-pessimist discourse is really a corollary to globalization. In this capacity, it should be considered as the charger horse of the latter and a strategy of total domination over the continent. This intuition was confirmed by Guèye through the detour of an explanation he gave in regard with laying responsibility at the victim's door. For the researcher, this responsibility-laying is deliberate strategy to persuade the African peoples that they are congenitally unsuited for controlling their own destiny, and that they need then to accept just to be the eternal lame ducks of history, fated to go forward only when pulled by others, that is, to be dominated by them. The morbid delight with which certain media, quite often with the pretext of political and social events which were deliberately 
magnified, caricatured or skipped for this very end, have strived to rouse and massively spread what was to be called "Afro-pessimism", may from this viewpoint be interpreted as an essential element of the enslaving strategy for our continent [Africa], of its imprisonment within a system of economic laws and ideological, political and cultural references that are dictated by the only needs of capitalistic globalization (Guèye 6).

The researcher emphasizes the point that this is the more true as the conditions that allowed the emergence of Afro-pessimistic discourse are quite suspect. This alarmist discourse is contemporaneous with the failure of adjustment "in order to ascribe the responsibility to our so-called "natural inability for any rational behavior, but also to present another plausible pretext to those who absolutely need this idea to perpetuate political domination and economic pressure. "(Guèye 6).

\section{References}

Angenot, Marc. 1889. Un état du discours social. Longueuil: Le préambule, 1989.

.La propagande socialiste. Six essais d'analyse du discours. Montréal: Balzac, 1997.

Chambers, Ross. Room for Maneuver: Reading (the) oppositional (in) Narrative. Chicago: University of Chicago Press, 1991.

Coquery-Vidrovitch, Catherine. "L'Afro-pessimisme au seuil du troisième millénaire». Clio en Afrique 3 (1997). 17 janvier 2002 <http://www.up.univ-mrs.fr/ $\sim$ wclioaf/numero/3/editorial/index.html.

Foucault, Michel. L'archéologie du savoir. Paris: Gallimard, 1969.

Kerbrat-Orecchioni, Catherine. L'implicite. A. Colin, 1986.

Lakoff, George and Mark Johnson. Metaphors we live by. Chicago, London: The University of Chicago Press, 1980.

Levallois, Michel. «Actualité de l'afro-pessimisme ». Afrique contemporaine. 179. 1996. (3-15).

Rufin, Jean Christophe. L'Empire et les nouveaux barbares. Paris : Editions Jean-Claude Lattès, 2001.

Guèye, Sémou Pathé. «Mondialisation : signification, défis et perspectives pour l'Afrique. http://www.pit-senegal.com/mondialisation.htm, 3/10/03. 
Rwanda Journal of Arts and Humanities, Volume 2 (2), 2017

Zartman, William I., dir. L'effondrement de l'Etat: désintégration et restauration du pouvoir légitime. Trad. Brigitte Delorme. Colorado : Lynne Reinner Publishers. Inc., 1995.

Ziegler, Jean. Les nouveaux maîtres du monde et ceux qui leur résistent. Paris : Fayard, 2002. 